\title{
Tumor necrosis factor- $\alpha$ downregulates the REIC/Dkk-3 tumor suppressor gene in normal human skin keratinocytes
}

\author{
KEN KATAOKA $^{1}$, NATSUMI MAEHARA ${ }^{2}$, YUKI AYABE ${ }^{1}$, HITOSHI MURATA ${ }^{2}$, \\ NAM-HO $\mathrm{HUH}^{2}$ and MASAKIYO SAKAGUCHI ${ }^{2}$ \\ ${ }^{1}$ Department of Life Science, Faculty of Science, Okayama University of Science, Okayama 700-0005; \\ ${ }^{2}$ Department of Cell Biology, Okayama University Graduate School of Medicine, \\ Dentistry and Pharmaceutical Sciences, Okayama 700-8558, Japan
}

Received September 24, 2015; Accepted July 14, 2016

DOI: $10.3892 / \mathrm{mmr} .2018 .8676$

\begin{abstract}
Our previous studies revealed that REIC/Dkk-3 was expressed various tissues, including skin keratinocytes. The aim of the present study was to identify the factors that regulate the expression of the dickkopf Wnt signaling pathway inhibitor 3 (REIC/Dkk-3) tumor suppressor gene in normal human skin keratinocytes (NHKs). Several growth factors and cytokines that have previously been reported to be involved in the growth and differentiation of keratinocytes were screened as potential regulators. Western blot analysis was performed using protein from NHKs cultured with/without various factors including the epidermal growth factor, tumor necrosis factor- $\alpha$, transforming growth factor- $\beta$, interleukin (IL)-1F9, IL-6, IL-8 and $\mathrm{Ca}^{2+}$. The results indicated that only TNF- $\alpha$ downregulated REIC/Dkk-3 expression in NHKs. Subsequently, TNF- $\alpha$ was confirmed to reduce the expression levels of REIC/Dkk-3 in mouse skin tissue and hair culture models. TNF- $\alpha$-mediated downregulation of REIC/Dkk-3 expression in NHKs was abrogated by the addition of a TNF- $\alpha$-specific antibody. In conclusion, the results indicate that TNF- $\alpha$ downregulates REIC/Dkk-3 expression in normal skin keratinocytes.
\end{abstract}

\section{Introduction}

Dickkopf Wnt signaling pathway inhibitor 3 (Dkk-3) is a member of the dickkopf (Dkk) family, and is also known as REIC due to its reduced expression in immortalized cells (1). Overexpression of REIC/Dkk-3 using an adenovirus vector has been demonstrated to induce growth suppression and/or apoptosis in a variety of cancer cells $(2,3)$. Other Dkk family

Correspondence to: Dr Ken Kataoka, Department of Life Science, Faculty of Science, Okayama University of Science, 1-1 Ridaicho, Kita-ku, Okayama 700-0005, Japan

E-mail: kenk@dls.ous.ac.jp

Key words: dickkopf Wnt signaling pathway inhibitor 3, tumor necrosis factor- $\alpha$, skin tissue, keratinocytes members, including Dkk-1, Dkk-2 and Dkk-4, interfere with the Wnt signaling pathway (4); however, the physiological function of REIC/Dkk-3 remains unclear. Previous studies investigating the expression pattern of REIC/Dkk-3 in normal and pathological skin tissues have demonstrated that the expression levels of REIC/Dkk-3 were evidently reduced, not only in skin cancer cells, but also in the normal skin keratinocytes surrounding cancer nodules $(5,6)$. In addition, the level of REIC/Dkk-3 expression was reduced in normal skin keratinocytes under inflammatory conditions (5). Other researchers also reported that negative or very low expression of REIC/Dkk-3 was observed in cutaneous squamous cell carcinoma tissues (7). However, the role of REIC/Dkk-3 in normal and/or cancer skin tissues is still unclear. Furthermore, cornified skin tissues were observed to express REIC/Dkk-3 at varying levels (6). These previous findings indicate that normal and/or cancer cells secrete a factor(s) that regulates REIC/Dkk-3. These unknown regulators of REIC/Dkk-3 expression may be potential therpeutic targets for skin cancer. Therefore, the aim of the present study was to identify the factors involved in the regulation of REIC/Dkk-3 in normal skin keratinocytes.

\section{Materials and methods}

Reagents. Recombinant human epidermal growth factor (EGF), transforming growth factor- $\beta$ (TGF- $\beta$ ), tumor necrosis factor- $\alpha(\mathrm{TNF}-\alpha)$ and interleukin (IL)- 6 were purchased from Peprotech, Inc. (Rocky Hill, NJ, USA). Recombinant IL-1F9 and IL-8 were purchased from R\&D Systems, Inc. (Minneapolis, MN, USA).

Animals. A total of 12 female C57BL/6 mice (age, 6-8 weeks; body weight, 16-22 g) were purchased from Clea Japan, Inc. (Hamamatsu, Japan) and maintained at $18-23^{\circ} \mathrm{C}$ with $40 \%$ humidity and a $12 \mathrm{~h}$ light/12 h dark cycle. Mice were fed with a normal mouse diet supplied by Clea Japan, Inc. and sacrified using excess amount of the anesthetic drug. For anesthesia, 2,2,2-tribromoethanol (cat. no. T1420; Tokyo Chemical Industry Co., Ltd., Tokyo, Japan) was injected intraperitoneally at a dose of $200 \mathrm{mg} / \mathrm{kg}$ body weight. Animal experiments were approved and performed in accordance 
with the guidelines of Okayama University (Okayama, Japan; permit no. OKU-2011105).

Cell culture. Normal human keratinocytes (NHKs) were purchased from Kurabo Industries, Ltd. (cat. no. KK-4009; Osaka, Japan) and cultured in HuMedia-KG2 (Kurabo Industries, Ltd.). NHKs were maintained at $37^{\circ} \mathrm{C}$ with $5 \%$ $\mathrm{CO}_{2}$ and incubated with $10 \mathrm{ng} / \mathrm{ml}$ of a specific neutralizing antibody against TNF- $\alpha$ (cat. no. D2H4; monoclonal rabbit antibody; Cell Signaling Technology, Inc., Danvers, MA, USA) for $24 \mathrm{~h}$ to abrogate TNF- $\alpha$ activity. Treatment of NHKs with the aforementioned recombinant protein factors was achieved by culturing NHKs with various concentrations of EGF $(0,10,50$ and $100 \mathrm{ng} / \mathrm{ml})$, TGF- $\beta(0,1,5$, $10 \mathrm{ng} / \mathrm{ml})$, TNF- $\alpha(0,10,50$ and $100 \mathrm{ng} / \mathrm{ml}), \operatorname{IL}-6(0,10,50$ and $100 \mathrm{ng} / \mathrm{ml})$, IL-8 $(0,10,50$ and $100 \mathrm{ng} / \mathrm{ml}), \operatorname{IL}-1 \mathrm{~F} 9(0,10$, 50 and $100 \mathrm{ng} / \mathrm{ml})$ and $\mathrm{Ca}^{2+}(0,0.5,1.5$ and $5 \mathrm{mM})$ for $24 \mathrm{~h}$. The concentrations used in the experiments were determined by previous studies $(8,9)$.

Tissue culture. Mice were clipped and skin tissue was collected from the back using an $8 \mathrm{~mm}$ biopsy punch (Maruho, Co., Ltd., Osaka, Japan). As shown in Fig. 1A, the mouse skin tissue was then placed on a piece of filter paper (Advantec MFS, Inc., Tokyo, Japan), and both edges of the paper were immersed in Dulbecco's modified Eagle's medium (Thermo Fisher Scientific, Inc., Waltham, MA, USA) supplemented with $10 \%$ fetal bovine serum, $100 \mu \mathrm{g} / \mathrm{ml}$ kanamycin (Meiji Seika Pharma Co., Ltd., Tokyo, Japan) and $0.5 \mu \mathrm{g} / \mathrm{ml}$ amphotericin B (Gibco;Thermo Fisher Scientific, Inc.). Hematoxylin and eosin staining of frozen tissue sections was performed using conventional methods $(5,6)$. Preliminary experiments demonstrated that the structure of skin tissue on the filter paper was maintained for $24 \mathrm{~h}$ (Fig. 1B). Skin tissue extracts were treated without or with $100 \mathrm{ng} / \mathrm{ml}$ recombinant TNF- $\alpha$. Hair follicles were plucked from the mouse upper lip with tweezers and incubated in the $\varnothing 35 \mathrm{~mm}$ culture dish (Corning Incorporated, Corning, NY, USA) without or with $100 \mathrm{ng} / \mathrm{ml}$ TNF- $\alpha$ in Dulbecco's modified Eagle's medium supplemented with $10 \%$ fetal bovine serum, $100 \mu \mathrm{g} / \mathrm{ml}$ kanamycin and $0.5 \mu \mathrm{g} / \mathrm{ml}$ amphotericin B for $24 \mathrm{~h}$.

Immunocytochemical and immunohistochemical analyses. Immunocytochemical detection of REIC/Dkk-3 in NHKs cultured on glass slide culture vessels (Thermo Fisher Scientific, Inc.) and tissue culture specimens was conducted as described previously $(5,6)$. Briefly, samples were fixed in cold acetone for $10 \mathrm{~min}$, washed with phosphate-buffered saline containing $0.05 \%$ Tween 20 (PBST), and incubated with a blocking solution (10\% skim milk, $6 \%$ glycine and $0.01 \mathrm{~N}$ $\mathrm{KOH}$ in PBST) at room temperature for $1 \mathrm{~h}$. Subsequently, the slides were incubated with goat polyclonal antibody against REIC/Dkk-3 (cat. no. AF1118; R\&D Systems, Inc.) at a 1:50 dilution at room temperature for $1 \mathrm{~h}$. Subsequent to washing with PBST, the tissue sections were again incubated with the blocking solution, followed by probing with polyclonal donkey antibody against goat $\operatorname{IgG}(\mathrm{H}+\mathrm{L})$ labeled with Alexa Fluor 488 dye (cat. no. A11055; Thermo Fisher Scientific, Inc.) at a 1:500 dilution. After washing with PBST, the tissue sections were mounted using VECTASHIELD with DAPI (Vector
A

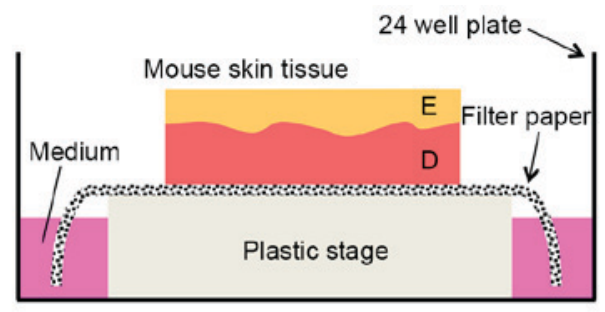

B

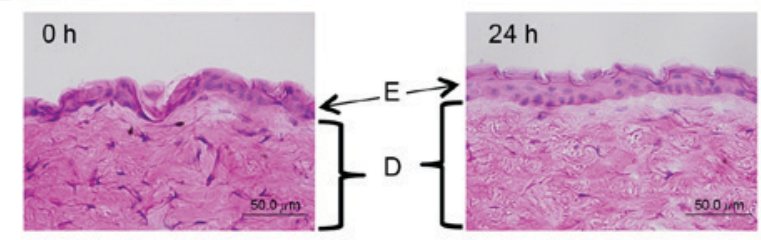

Figure 1. Mouse skin tissue culture model. (A) Schematic illustration of the method used to culture adult mouse skin tissue extracts. (B) Hematoxylin and eosin staining of mouse skin tissues at 0 and $24 \mathrm{~h}$ of incubation. D, dermis; E, Epidermis.

Laboratories, Inc., Burlingame, CA, USA). Normal goat IgG was used as a negative control for the primary antibody.

Preparation of protein lysates and western blot analysis. Protein extracts $(10 \mu \mathrm{g})$ were obtained by lysing cells in mammalian protein extraction reagent (M-PER; Thermo Fisher Scientific, Inc.), and were subsequently used for western blot analysis. Protein from the tissue culture medium was prepared as described previously (10). Briefly, the culture medium was mixed with an equal volume of acetone and incubated at $-20^{\circ} \mathrm{C}$ for $24 \mathrm{~h}$. Protein in the medium was precipitated by centrifugation at $12,000 \mathrm{x} \mathrm{g}$ for $20 \mathrm{~min}$ at $4^{\circ} \mathrm{C}$ and the pellet was reconstituted into the same volume $(\sim 50 \mu \mathrm{l})$ of M-PER as that of the cell extracts. The concentration of protein extracts from the cell lysates and the tissue culture medium was determined using a Bio-Rad protein assay (cat. no. 500-0006JA; Bio-Rad Laboratories, Inc., Hercules, CA, USA), and the same volume of protein extract ( $10 \mu \mathrm{g}$ protein extract) obtained from both samples was used for western blot analysis. Western blot analysis was performed using $10 \mu \mathrm{g}$ of protein extracts and the procedures described previously (5). Briefly, extracted protein samples were separated by $4-20 \%$ polyacrylamide gel electrophoresis and transferred onto polyvinylidene difluoride membranes (GE Healthcare Life Sciences, Chalfont, UK). After blocking in $10 \%$ skim milk, the membranes were incubated with primary antibodies at a 1:500 dilution at $4^{\circ} \mathrm{C}$ overnight. The membranes were then washed with PBS, incubated with secondary antibodies at a 1:1,000 dilution at room temperature for $1 \mathrm{~h}$ and rinsed with PBS. The antibodies used were as follows: Rabbit anti-REIC/Dkk-3 antibody raised in our laboratory (Okayama University of Science, Okayama, Japan), monoclonal mouse anti-tubulin antibody (cat. no. T5168; Sigma-Aldrich, St Louis, MO, USA), and horseradish peroxidase-linked anti-rabbit IgG secondary antibody (cat. no. 7074; Cell Signaling Technology, Inc.) or anti-mouse IgG secondary antibody (cat. no. 7076; Cell Signaling Technology, Inc.). Signals were visualized using the Enhanced Chemiluminescence Plus detection reagent (GE Healthcare Life Sciences). 
Reverse transcription-polymerase chain reaction (RT-PCR) analysis. Total RNA was isolated from cultured NHKs using the SV Total RNA Isolation system (Promega Corporation, Madison, WI, USA) and pretreated with DNase I according to the manufacturer's instructions. RT to generate cDNA was performed using the SuperScript II First-Strand Synthesis system (Thermo Fisher Scientific, Inc.). Total RNA was incubated with oligo dT primer, dNTP mixture and reverse transcriptase at $42^{\circ} \mathrm{C}$ for $50 \mathrm{~min}$. PCR analysis of human REIC/Dkk-3 mRNA expression levels was conducted using isolated RNA (10 $\mu \mathrm{g})$ as described previously (11). Briefly, cDNA was amplified by ExTaq (cat.no. RR001; Takara Bio,Inc., Otsu, Japan) under the following conditions: Initial incubation at $94^{\circ} \mathrm{C}$ for $4 \mathrm{~min}$ followed by 30 cycles at $94^{\circ} \mathrm{C}$ for $30 \mathrm{sec}, 55^{\circ} \mathrm{C}$ for $30 \mathrm{sec}, 72^{\circ} \mathrm{C}$ for $30 \mathrm{sec}$, and then a final step at $72^{\circ} \mathrm{C}$ for $5 \mathrm{~min}$. GAPDH was used as an internal control. The primers used for PCR analysis were as follows: Human REIC/Dkk-3, forward 5'-CAGTTATCACATCTGTGGGAGACGAA-3' and reverse 5'-AACTTCATACTCATCGGGGACCTCT-3'; GAPDH, forward 5'-GGGTGTGAACCATGAGAAGTATGA-3' and reverse 5'-TGCTAAGCAGTTGGTGGTGC-3'. The PCR products were examined for specificity via $1.5 \%$ agarose gel electrophoresis and visualized by ethidium bromide.

\section{Results}

Screening of factors regulating REIC/Dkk-3 expression in human keratinocytes. In order to identify factors that regulate REIC/Dkk-3 expression in normal human skin keratinocytes, NHK cells were treated with growth factors and cytokines that are reportedly involved in keratinocyte growth and differentiation, including EGF, TGF- $\beta$, TNF- $\alpha$, IL-1F9, IL-6, IL- 8 and $\mathrm{Ca}^{2+}(8,9)$. The protein expression levels were then determined by western blot analysis $(12,13)$. As shown in Fig. 2, among these seven factors, only TNF- $\alpha$ was observed to downregulate REIC/Dkk-3 protein expression levels in NHKs. Downregulation of REIC/Dkk-3 by TNF- $\alpha$ was observed in both the cell extracts and tissue culture medium. IL- 8 treatment appeared to increase REIC/Dkk-3 expression in the cell extract, but not in the culture medium.

Downregulation of REIC/Dkk-3 in skin tissues by TNF- $\alpha$. Since the study identified that TNF- $\alpha$ treatment was able to reduce the expression of REIC/Dkk-3, its effect in tissue culture models of mouse skin were further investigated. Following in vitro incubation with $100 \mathrm{ng} / \mathrm{ml} \mathrm{TNF}-\alpha$ for $24 \mathrm{~h}$, REIC/Dkk-3 expression in the mouse epidermis was downregulated when compared with that in the untreated epidermis tissue extracts (Fig. 3). Consistent with these observations, plucked hair follicles incubated with $100 \mathrm{ng} / \mathrm{ml} \mathrm{TNF}-\alpha$ exhibited a reduction in REIC/Dkk-3 expression compared with the untreated mouse hair follicles (Fig. 4).

Abrogation of TNF- $\alpha$-mediated downregulation of REIC/Dkk-3 using a neutralizing anti-TNF- $\alpha$ antibody. In order to verify the effect of TNF- $\alpha$ treatment on the expression levels of REIC/Dkk-3, a competition assay was performed in NHKs using a specific neutralizing antibody against TNF- $\alpha$. Immunocytochemical analysis demonstrated that treatment of NHKs with the anti-TNF- $\alpha$
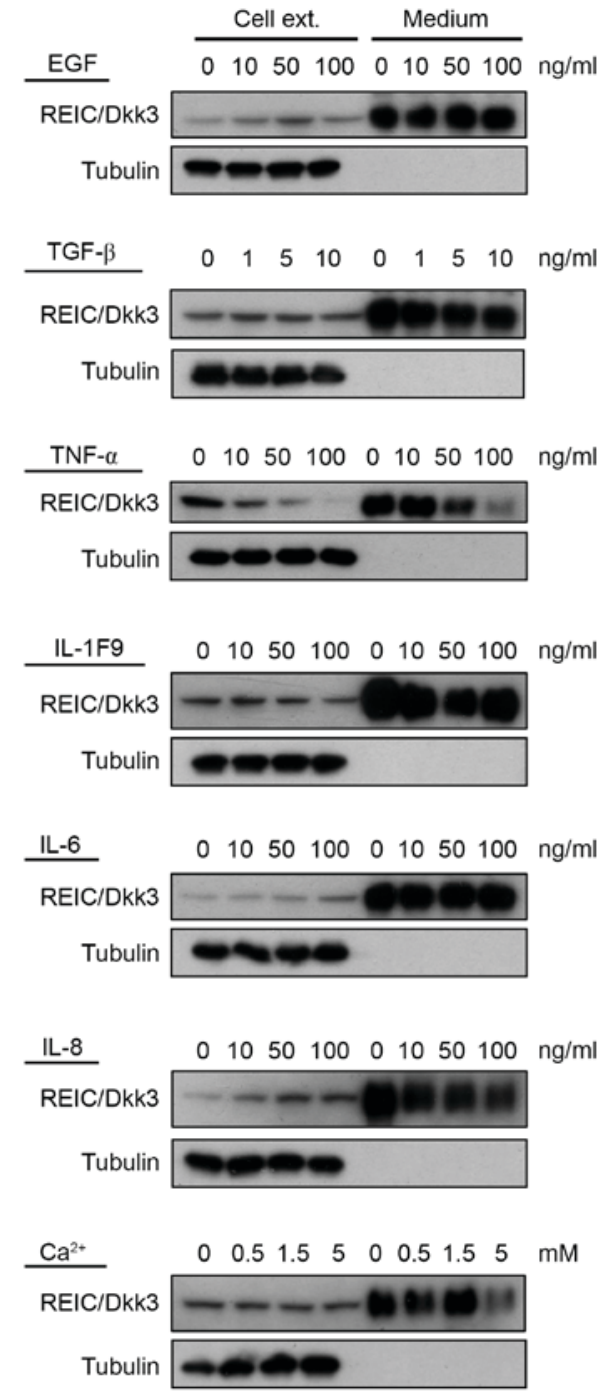

Figure 2. Identification of factors that regulate REIC/Dkk3 in NHKs and mouse skin tissue extracts. Western blot analysis was used to determine the REIC/Dkk-3 protein expression in cultured NHK cells following treatment with EGF, TGF- $\beta$, TNF- $\alpha$, IL-1F9, IL- 6 , IL- 8 and $\mathrm{Ca}^{2+}$. Tubulin was used as a control for the amount of protein in preparations. Cell ext., culture cell extract; Medium, culture medium; REIC/Dkk-3, dickkopf Wnt signaling pathway inhibitor 3; NHK, normal human keratinocyte; EGF, epidermal growth factor; TGF- $\beta$, transforming growth factor- $\beta$; TNF- $\alpha$, tumor necrosis factor- $\alpha$; IL, interleukin.

antibody abrogated the TNF- $\alpha$-mediated downregulation of REIC/Dkk-3 expression (Fig. 5). Similar results were obtained by western blot (Fig. 6A) and RT-qPCR analyses (Fig. 6B) of the REIC/Dkk-3 protein and mRNA expression levels in NHK cells, respectively.

\section{Discussion}

REIC/Dkk-3 is considered to be a tumor suppressor gene as its expression levels are reduced in numerous human malignancies (1). Previous studies have demonstrated that the REIC/Dkk-3 promoter region is frequently methylated in several malignant tissues, particularly in breast cancer tissues $(14,15)$. However, Saeb-Parsy et al (16), reported that knockdown of the membrane type-1 matrix metalloproteinase induced upregulation of REIC/Dkk-3 expression in human 


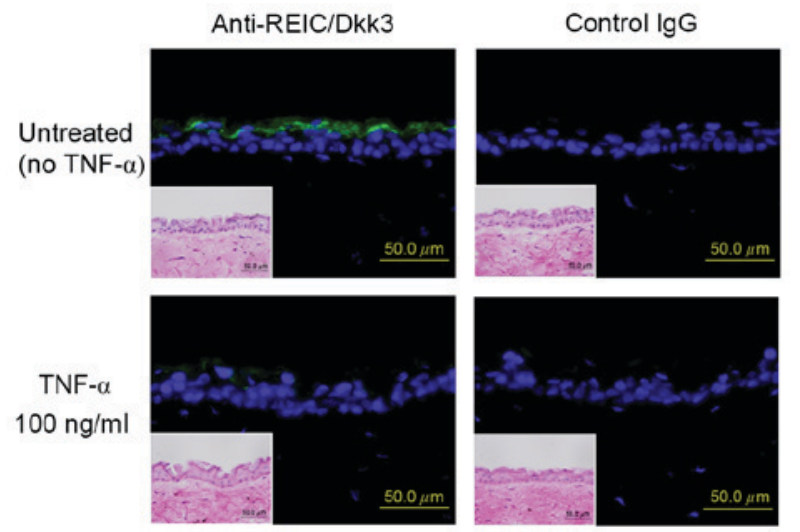

Figure 3. Downregulation of REIC/Dkk-3 expression in the intrafollicular epidermis of mouse skin tissue by TNF- $\alpha$. Skin tissue obtained from adult mice was cultured with or without $100 \mathrm{ng} / \mathrm{ml} \mathrm{TNF-} \alpha$ for $24 \mathrm{~h}$. Skin tissue sections were stained for REIC/Dkk-3 (green), and IgG was used as a negative control. Nuclei were stained with DAPI (blue). REIC/Dkk-3, dickkopf Wnt signaling pathway inhibitor 3 ; TNF- $\alpha$, tumor necrosis factor- $\alpha$.

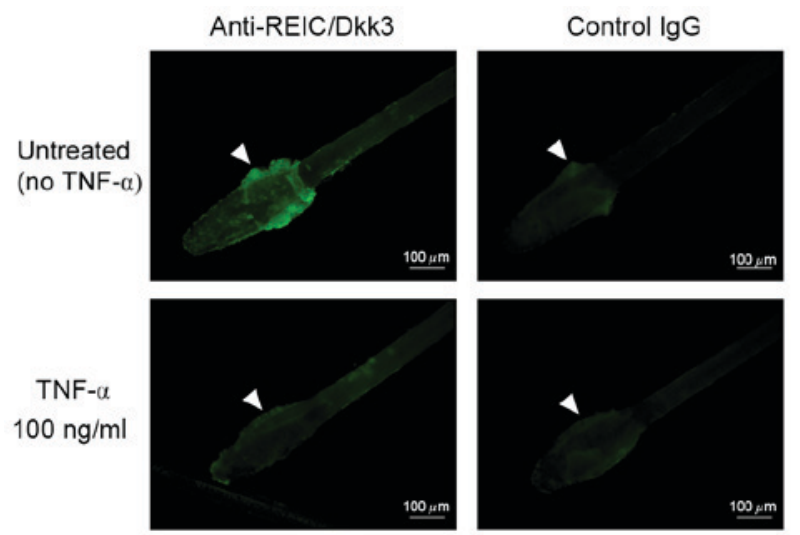

Figure 4. TNF- $\alpha$-mediated downregulation of REIC/Dkk-3 expression in mouse hair follicles. Hair follicles were plucked from the mouse upper lip and incubated without or with $100 \mathrm{ng} / \mathrm{ml} \mathrm{TNF}-\alpha$ for $24 \mathrm{~h}$. Incubated follicles were stained for REIC/Dkk-3 (green). Arrowheads indicate the positive signals at the isthmus region of the plucked hair follicles. IgG was used as a negative control. TNF- $\alpha$, tumor necrosis factor- $\alpha$; REIC/Dkk-3, dickkopf Wnt signaling pathway inhibitor 3 .

urothelial carcinoma cells. Thus, the mechanisms by which REIC/Dkk-3 expression is regulated in normal and cancer cells are not fully understood.

In the present study, a number of growth factors and cytokines were screened as potential regulators of REIC/Dkk-3 expression in normal skin keratinocytes. Among the seven factors screened, only TNF- $\alpha$ was observed to downregulate REIC/Dkk-3 expression in NHKs. The skin tissue culture model employed in the present study maintained a high level of REIC/Dkk-3 expression for $24 \mathrm{~h}$. A reduction in REIC/Dkk-3 expression following TNF- $\alpha$ treatment was confirmed using this skin tissue culture model, as well as the incubated hair follicles, via by immunohistochemistry analysis (Figs. 3 and 4). In addition, TNF- $\alpha$-mediated downregulation of REIC/Dkk-3 in NHKs was abrogated by the treatment of cells with a neutralizing TNF- $\alpha$-specific antibody.

TNF- $\alpha$ is a proinflammatory cytokine that is involved in the early-phase reaction of skin inflammation $(12,17,18)$. TNF- $\alpha$ is

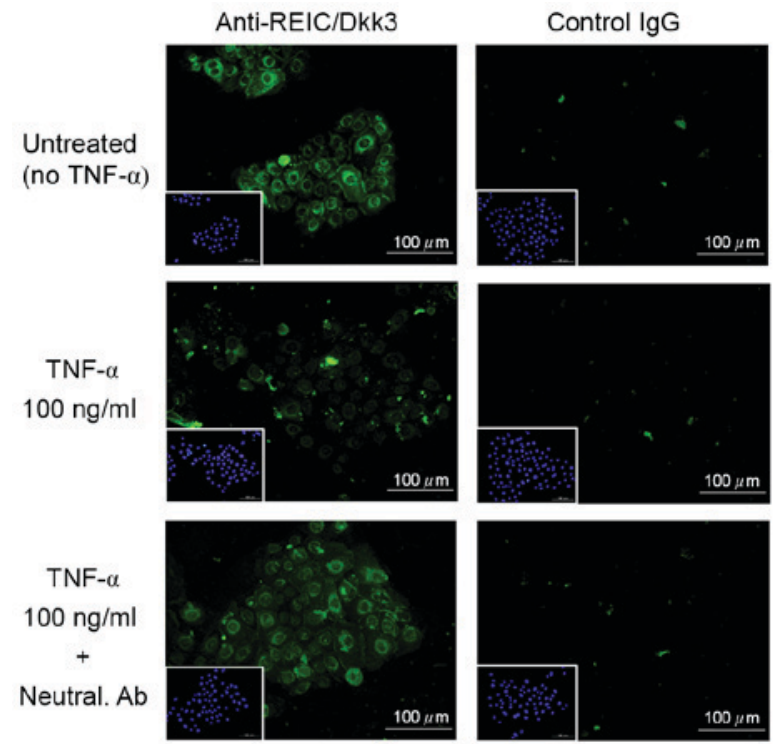

Figure 5. Abrogation of TNF- $\alpha$-mediated downregulation of REIC/Dkk-3 using an anti-TNF- $\alpha$ antibody. Immunostaining of REIC/Dkk-3 in NHK cells following treatment with TNF- $\alpha$ only or TNF- $\alpha$ in combination with a neutralizing anti-TNF- $\alpha$ antibody. Inset images show NHK cells stained with DAPI. TNF- $\alpha$, tumor necrosis factor- $\alpha$; REIC/Dkk-3, dickkopf Wnt signaling pathway inhibitor 3; NHK, normal human keratinocytes.

A

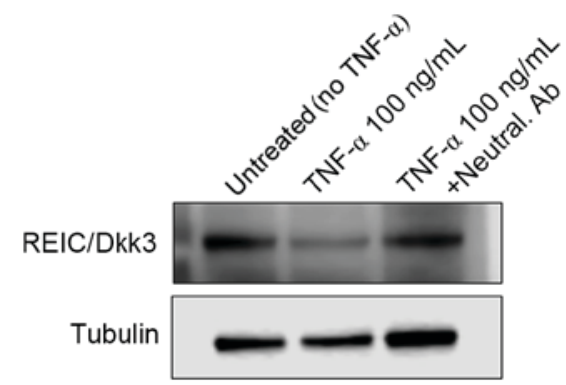

B

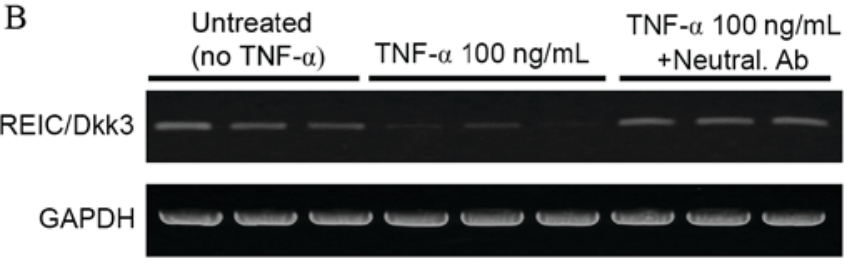

Figure 6. Abrogation of TNF- $\alpha$-mediated downregulation of REIC/Dkk-3 in NHK cells using a neutralizing anti-TNF- $\alpha$ antibody as detected by (A) western blot analysis and (B) reverse transcription-quantitative polymerase chain reaction (PCR) analysis of REIC/Dkk-3 protein and mRNA expression levels, respectively. Lanes show the PCR products from independent culture dishes. GAPDH was used as an endogenous control. TNF- $\alpha$, tumor necrosis factor- $\alpha$; REIC/Dkk-3, dickkopf Wnt signaling pathway inhibitor 3; NHK, normal human keratinocytes.

expressed in pathological skin tissues, including hyperproliferative, ultraviolet-irradiated and wounded epidermis (19-21). TNF- $\alpha$ inhibitors have been used previously for the treatment of psoriasis and psoriatic arthritis $(22,23)$. In a previous study, enhanced REIC/Dkk-3 expression was observed in hyperproliferative epidermal tissues, such as tissues in psoriasis and other inflammatory diseases (5). In addition, a downregulation of REIC/Dkk-3 expression was observed in skin tissues following 
wound healing. These results suggest that REIC/Dkk-3 may serve a pivotal role in the regeneration of damaged skin tissues.

Following the exposure of skin keratinocytes, fibroblasts and other cells to TNF- $\alpha$ in vitro, keratinocytes exhibited an upregulation in mesenchymal markers and demonstrated an increased migration potential (24). These features are indicators of epithelial-mesenchymal transition (EMT), which is observed during wound healing. Treatment of dermal fibroblasts with TNF- $\alpha$ resulted in increased matrix metalloproteinase activity and enhanced cell migration capabilities in vitro (25). In addition, TNF- $\alpha$ induced the production of adhesion molecules and cytokines that mobilize immune cells into skin tissue (26). Cytokines produced by immune cells induced the proliferation and differentiation of keratinocytes, which led to skin tissue remodeling. Furthermore, stimulated keratinocytes produced cytokines to stimulate the surrounding keratinocytes and immune cells (27). The sequential stimulation of skin cells by secreted cytokines is an essential event during skin inflammation and skin tissue remodeling.

Lee et al (28), reported that activated human mesenchymal stem/stromal cells (hMSCs) secreted REIC/Dkk-3 to suppress the cell cycle progression in MDA-MB-231 breast cancer cells (28). In addition, it was demonstrated that REIC/Dkk-3 protein expression levels were upregulated in hMSCs following incubation of the cells with TNF- $\alpha$ (28). However, these previous observations contradict the results of the present study, where TNF- $\alpha$ was demonstrated to decarease REIC/Dkk-3 protein expression levels. Since these observations are contradictory, further studies are required to understand REIC/Dkk-3 regulation in different cell types.

In conclusion, the present study demonstrated that TNF- $\alpha$ reduced the expression of REIC/Dkk-3 in mouse skin keratinocytes and NHKs. This was confirmed by the observation that TNF- $\alpha$ reduced the expression of REIC/Dkk-3 in tissue culture models of mouse skin and hair. These results suggest that REIC/Dkk-3 may serve a pivotal role in skin inflammation and tissue remodeling.

\section{Acknowledgements}

Not applicable.

\section{Funding}

The present study was supported in part by the Japan Society for the Promotion of Science, Grants-in-Aid for Scientific Research KAKENHI (grant nos. 24591943, 26106725 and 15K01303; awarded to KK).

\section{Availability of data and materials}

The analyzed data sets generated during the study are available from the corresponding author on reasonable request.

\section{Authors' contributions}

KK and NH conceived the study. KK, NM, YA, HM and MS performed the analysis. KK and MS wrote the paper. All authors read and approved the manuscript.

\section{Ethics approval and consent to participate}

Ethical approval for the animal study was provided by Okayama University Animal Care and Use Committee (Okayama, Japan).

\section{Consent for publication}

Not applicable.

\section{Competing interests}

The authors declare that they have no competing interests.

\section{References}

1. Tsuji T, Miyazaki M, Sakaguchi M, Inoue Y and Namba M: A REIC gene shows down-regulation in human immortalized cells and human tumor-derived cell lines. Biochem Biophys Res Commun 268: 20-24, 2000

2. Watanabe M, Nasu Y and Kumon H: Adenovirus-mediated REIC/Dkk-3 gene therapy: Development of an autologous cancer vaccination therapy (Review). Oncol Lett 7: 595-601, 2014.

3. Abarzua F, Sakaguchi M, Takaishi M, Nasu Y, Kurose K, Ebara S, Miyazaki M, Namba M, Kumon H and Huh NH: Adenovirus-mediated overexpression of REIC/Dkk-3 selectively induces apoptosis in human prostate cancer cells through activation of c-Jun-NH2-kinase. Cancer Res 65: 9617-9622, 2005.

4. Niehrs C: Function and biological roles of the Dickkopf family of Wnt modulators. Oncogene 25: 7469-7481, 2006.

5. Du G, Kataoka K, Sakaguchi M, Abarzua F, Than SS, Sonegawa H, Makino T, Shimizu T and Huh NH: Expression of REIC/Dkk-3 in normal and hyperproliferative epidermis. Exp Dermatol 20: 273-277, 2011.

6. Kataoka K, Du G, Maehara N, Murata H, Sakaguchi M and Huh N: Expression pattern of REIC/Dkk-3 in mouse squamous epithelia. Clin Exp Dermatol 37: 428-431, 2012.

7. Shin JM, Choi DK, Kang HY, Sohn KC, Lee Y, Kim CD, Lee JH and Park BC: The expression pattern and functional role of REIC/Dkk-3 in the development of cutaneous squamous cell carcinoma. J Dermatol Sci 84: 88-96, 2016.

8. Sakaguchi M, Sonegawa H, Murata H, Kitazoe M, Futami J, Kataoka K, Yamada H and Huh NH: S100A11, an dual mediator for growth regulation of human keratinocytes. Mol Biol Cell 19: 78-85, 2008

9. Sakaguchi M, Miyazaki M, Takaishi M, Sakaguchi Y, Makino E, Kataoka N, Yamada H, Namba M and Huh NH: S100C/A11 is a key mediator of $\mathrm{Ca}(2+)$-induced growth inhibition of human epidermal keratinocytes. J Cell Biol 163: 825-835, 2003.

10. Nukui T, Ehama R, Sakaguchi M, Sonegawa H, Katagiri C, Hibino T and Huh NH: S100A8/A9, a key mediator for positive feedback growth stimulation of normal human keratinocytes. J Cell Biochem 104: 453-464, 2008.

11. Than SS, Kataoka K, Sakaguchi M, Murata H, Abarzua F, Taketa C, Du G, Yashiro M, Yanagihara K, Nasu Y, et al: Intraperitoneal administration of an adenovirus vector carrying REIC/Dkk-3 suppresses peritoneal dissemination of scirrhous gastric carcinoma. Oncol Rep 25: 989-995, 2011.

12. Barrientos S, Stojadinovic O, Golinko MS, Brem H and Tomic-Canic M: Growth factors and cytokines in wound healing. Wound Repair Regen 16: 585-601, 2008.

13. Tuschil A, Lam C, Haslberger A and Lindley I: Interleukin-8 stimulates calcium transients and promotes epidermal cell proliferation. J Invest Dermatol 99: 294-298, 1992.

14. Hayashi T, Asano H, Toyooka S, Tsukuda K, Soh J, Shien T, Taira N, Maki Y, Tanaka N, Doihara H, et al: DNA methylation status of REIC/Dkk-3 gene in human malignancies. J Cancer Res Clin Oncol 138: 799-809, 2012.

15. Veeck J and Dahl E: Targeting the Wnt pathway in cancer: The emerging role of Dickkopf-3. Biochim Biophys Acta 1825: 18-28, 2012.

16. Saeb-Parsy K, Veerakumarasivam A, Wallard MJ, Thorne N, Kawano Y, Murphy G, Neal DE, Mills IG and Kelly JD: MT1-MMP regulates urothelial cell invasion via transcriptional regulation of Dickkopf-3. Br J Cancer 99: 663-669, 2008. 
17. Bashir MM, Sharma MR and Werth VP: TNF-alpha production in the skin. Arch Dermatol Res 301: 87-91, 2009.

18. Tracey D, Klareskog L, Sasso EH, Salfeld JG and Tak PP: Tumor necrosis factor antagonist mechanisms of action: A comprehensive review. Pharmacol Ther 117: 244-279, 2008.

19. Ettehadi P, Greaves MW, Wallach D, Aderka D and Camp RD: Elevated tumour necrosis factor-alpha biological activity in psoriatic skin lesions. Clin Exp Immunol 96: 146-151, 1994.

20. Köck A, Schwarz T, Kirnbauer R, Urbanski A, Perry P, Ansel JC and Luger TA: Human keratinocytes are a source for tumor necrosis factor alpha: Evidence for synthesis and release upon stimulation with endotoxin or ultraviolet light. J Exp Med 172: $1609-1614,1990$

21. Singer AJ and Clark RA: Cutaneous wound healing. N Engl J Med 341: 738-746, 1999.

22. Palladino MA, Bahjat FR, Theodorakis EA and Moldawer LL: Anti-TNF-alpha therapies: The next generation. Nat Rev Drug Discov 2: 736-746, 2003
23. Lebrec H, Ponce R, Preston BD, Iles J, Born TL and Hooper M: Tumor necrosis factor, tumor necrosis factor inhibition, and cancer risk. Curr Med Res Opin 31: 557-574, 2015.

24. Yan C, Grimm WA, Garner WL, Qin L, Travis T, Tan N and Han YP: Epithelial to mesenchymal transition in human skin wound healing is induced by tumor necrosis factor-alpha through bone morphogenic protein-2. Am J Pathol 176: 2247-2258, 2010.

25. Choi JY, Piao MS, Lee JB, Oh JS, Kim IG and Lee SC: Propionibacterium acnes stimulates pro-matrix metalloproteinase-2 expression through tumor necrosis factor-alpha in human dermal fibroblasts. J Invest Dermatol 128: 846-854, 2008.

26. Liu Y, Krueger JG and Bowcock AM: Psoriasis: Genetic associations and immune system changes. Genes Immun 8: 1-12, 2007.

27. Bak RO and Mikkelsen JG: Regulation of cytokines by small RNAs during skin inflammation. J Biomed Sci 17: 53, 2010.

28. Lee RH, Yoon N, Reneau JC and Prockop DJ: Preactivation of human MSCs with TNF- $\alpha$ enhances tumor-suppressive activity. Cell Stem Cell 11: 825-835, 2012. 